\title{
THE INFLUENCE OF THE CETANE NUMBER AND LUBRICITY IMPROVING ADDITIVES ON THE QUALITY PARAMETERS OF AVIATION-TURBINE FUEL
}

\author{
Valentina VILUTIENE் ${ }^{1}$, Gvidonas LABECKAS ${ }^{2}$, Stasys SLAVINSKAS ${ }^{3}$ \\ ${ }^{1}$ The Department of Engineering Management, General Jonas Žemaitis Military Academy of Lithuania, \\ Šilo g. 5A, LT-10322 Vilnius, Lithuania \\ 2, 3 Institute of Power and Transport Machinery Engineering, Aleksandras Stulginskis University, \\ Studentu g. 15, LT-53362 Akademija, Kauno r., Lithuania \\ E-mails: 1valentina.vilutiene@mil.lt (correspondingauthor); ${ }^{2}$ gvidonas.labeckas@asu.lt; \\ 3stasys.slavinskas@asu.lt
}

Received 7 April 2014; accepted 19 May 2015

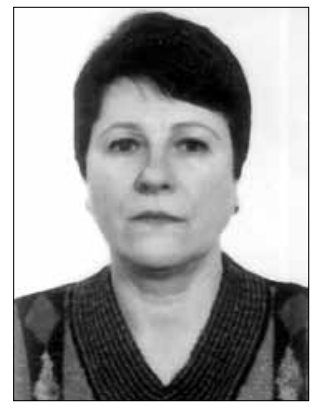

Valentina VILUTIENĖ, Dr Sc. Assoc. Prof.

Education: 1995 - The General Jonas Žemaitis Military Academy of Lithuania, Lithuania. 1978 - The Institute of Chemistry and Chemical Technology of the Lithuanian Academy of Sciences, Lithuania.

1969 - Vilnius University, Lithuania.

Research interests: military environmental protection, protection of metals against corrosion, applied chemistry, theory of explosive and fuel materials.

Publications: author of more than 60 publications.

Present position: Associate Professor of the Department of Engineering Management of Military Academy of Lithuania.

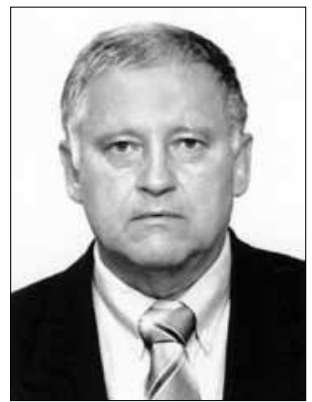

Gvidonas LABECKAS, Prof. Dr

Research interest: heat engines, including - internal combustion engines, diesel engines, biofuels, fuel injection and atomisation, autoignition, combustion, heat release, engine performance, emissions, smoke opacity.

Present position: Professor at Institute of Power and Transport Machinery Engineering of Aleksandras Stulginskis University.

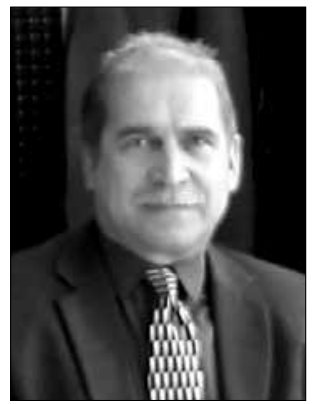

Stasys SLAVINSKAS, Dr Sc. Eng.

Date of birth: 1959.

Education: 1982 - Diploma of Mechanical Engineer, Lithuanian Agriculture Academy. 1991 -

Dr sc. eng., The Moscow Automobile and Road Construction Institute (MADI)

Research interest: Internal Combustion Engines, Alternative fuels.

Publications: over 70 scientific papers.

Present position: Professor, Director of the Institute of Power and Transport Machinery

Engineering at Aleksandras Stulginskis University.

Abstract. In order to recommend jet fuel for powering diesel engines the quality parameters of the following fuels were determined: diesel fuel (NATO code F-54) according to standard LST EN 590: 2014, jet fuel (NATO code F-35 and F-34) according to standard ASTM D 1655 and U.S.MIL-DTL-83133E, and jet fuel was treated with additives at the Centre of Quality research laboratory located at "ORLEN Lietuva" Ltd. Basic quality parameters of alternative jet fuels were analysed and compared with the reference parameters of diesel fuel. It was determined that the use of 
additives in jet fuel improves its parameters up to a level which satisfies the corresponding characteristics of normal diesel fuel: cetane number, lubricating properties, net heating value per unit of mass, sulphur content and, therefore, can be recommended for the use in land-based transport means and power generators.

Keywords: diesel engine, jet fuel, diesel fuel, fuel property parameters.

\section{Introduction}

The department of Engineering management of General Jonas Žemaitis Military Academy of Lithuania in cooperation with the scientists of Power and Transport Machinery Engineering Institute of Aleksandras Stulginskis university implemented the scientific project "Research on the possibilities of using aviation and other alternative fuels in ground transport means of the Lithuanian Army". Since mineral fuel resources such as petroleum-based fuels are decreasing, research works that may initiate more effective use of mineral (non-renewable) resources and increase the use of alternative fuels made on the basis of renewable resources are currently of particular importance (McDonnell et al. 2000; EN 590: 2014).

A large number of research works on the use of biofuels has been carried out worldwide; however, no unambiguous answer has been provided to the question, what is the recommended diesel fuel and biofuel blending ratio in alternative fuel (Graboski, McCormick 1998; Labeckas, Slavinskas 2006). Also, no comprehensive investigation on the indicators of jet fuels and blends of jet fuels and biofuels that could be used in diesel engines as an alternative fuel has been carried out (Lotko et al. 2000; Nwafor 2004). Changes of physical and chemical properties of biofuels and their blends may be controlled to some extent when using jet fuels such as aviation kerosene, blends of jet fuels and commercial diesel fuels as well as fuel additives (Specification DCSEA 108/A: 2001).

The department of Engineering Management of General Jonas Žemaitis Military Academy of Lithuania is involved in the implementation of the scientific project "The Investigation on Using Aviation Fuel and Other Alternative Fuels in Road Vehicles of the Lithuanian Army" in cooperation with the scientists from Aleksandras Stulginskis University's Power and Transport Machinery Engineering Institute. Within the scope of this project, the influence of commercial diesel fuel and jet fuels as well as multipurpose additives on quality parameters of the fuel, performance efficiency of diesel engines and controlled emissions produced by the combustion of various alternative fuels are analysed using laboratory engine tests.

Research results of a part of the project related to the quality parameters of jet fuel are analysed and compared in this paper.

\section{NATO fuels}

\section{Ground fuels:}

F-67 - unleaded gasoline automotive (minimum 95 RON).

\section{Aviation fuels:}

F-34 -a kerosene turbine type aviation fuel (known as JP-8 or AVTUR/FSII) for using in land based military aircraft gas turbine engines. The fuel contains a fuel system anti-icing inhibitor S-1745 and a lubricity improving additive $\mathrm{S}-1747$.

F-35 - a kerosene turbine type aviation fuel (known as Jet-A1 or AVTUR) for using in land based military aircraft gas turbine engines. It is equivalent to F-34 but does not contain the additives S-1745 and S-1747.

\section{Diesel fuels:}

F-54 - a diesel fuel (EN 590: 2014) used in compression ignition engines.

F-63 - a kerosene type diesel engine fuel. It is produced on the basis of F-34 or F-35 treated with $0.1 \%$ volume of multipurpose additive S-1750. This fuel is to be used in land equipment only and must not be used for aircraft. S-1750 is a combined lubricity and ignition improving additive for ground fuels.

\section{Single fuel policy}

In the year 2004, NATO Committee approved the Single Fuel Policy (NATO 1997). The Single Fuel Policy means that in military road vehicles and other transport means, equipped with diesel engines and operating on self-ignited combustible in-cylinder compressed air and diesel fuel mixture, this fuel should be replaced with aviation kerosene widely available in Europe, otherwise referred to as jet fuel.

The replacement of diesel fuel with jet fuel will be completed in three phases. The first phase has already been completed. Large-fraction turbine aviation fuel F-40 usually used for training purposes was replaced by kerosene-type aviation fuel F-34 usable for land-based military aircraft.

In the second phase, diesel fuel F-54 for land-based vehicles and equipment with compression ignition engines or turbine engines dislocated in a battle-field is currently being replaced by F-34. In this phase, NATO Member States and Partner States are carrying out the work individually, according to their equipment replacement programmes, and taking into account the goals of the military forces and the partnership. 
In the third phase, a full-scale replacement of petrol (gasoline) F-67 in military operations, i.e. for military purposes, is planned. Conformity of the aviation fuel F-34 to the global quality standard stimulates the introduction of the Single Fuel Policy.

The attempts of the French Army to use the unified fuels were recognized by NATO as being successful (Specification DCSEA 751/B: 2000). From the logistic point of view, it is beneficial to supply a single fuel to the Army and to ensure favourable conditions for proper dislocation of energy resources within the sites of actions. Since 1999, French military equipment in the phase of design is adapted for operation with diesel fuel F-54 or jet diesel fuel F-63 (The representation... 2007).

\section{The object of the research and methods applied}

In order to use jet fuels in diesel engines the quality parameters of the following fuels have been established:

1. Diesel fuel (NATO code F-54) according to the provisions of LST EN 590;

2. Jet fuel Jet A-1 (NATO code F-35) according to the provisions of ASTM-D 1655;

3. Jet fuel for military purposes JP-8 (NATO code F-34) according to the provisions of U.S.MIL-DTL-83133E and DEF STAN 91-91 AVTUR/FSII.

The quality parameters, such as density, specific energy, the cetane number, lubricating properties, cold filter plugging point for diesel fuels and freezing point for jet fuels, sulphur content, etc. were measured in "ORLEN Lietuva" Ltd, in the laboratory of the Quality Research Centre approved by NATO.

The effect of additives on the quality parameters of jet fuels was investigated, their conformity to the quality parameters of diesel fuels was verified and a comparative analysis of the indicators of jet fuels and diesel fuel was carried out.

Density, the mass per unit volume of fuel, expressed in $\mathrm{kg} / \mathrm{m}^{3}$ or $\mathrm{g} / \mathrm{cm}^{3}$, is measured at the temperature of $15{ }^{\circ} \mathrm{C}$. The density of oil products mainly depends on their chemical composition and temperature. The density of molecular hydrocarbons with a lower content of carbon $\mathrm{C}$ is lower. Overall energy of lighter hydrocarbons is higher, because the specific energy of hydrogen is higher as compared to that of carbon.

Specific energy (net heating value) is a key quality indicator of fuel, it is the thermal energy generated by the combustion of $1 \mathrm{~kg}$ of fuel and is usually measured in $\mathrm{MJ} / \mathrm{kg}$.

Fuel is a complex substance, and it is difficult to determine its chemical composition. So, for investigation of fuel properties, its chemical composition in terms of elements is usually identified. Combustible elements of the fuel include carbon $\mathrm{C}$, hydrogen $\mathrm{H}$, and sulphur $\mathrm{S}$, non-combustible elements include nitrogen $\mathrm{N}$, oxygen $\mathrm{O}$, ash $\mathrm{A}$, and moisture $\mathrm{W}$.
The composition of fuel $\mathrm{K}$ can be expressed in mass percentage as (Jučas 1999):

$$
K=C+H+O+N+S+A+W=100 \% .
$$

If the elements of the fuel are identified, it is possible to calculate the specific energy of the fuel by adding the specific energies of all included elements.

When the combustible elements of the fuel oxidize, they release thermal energy $(\mathrm{MJ} / \mathrm{kg})$ : carbon $\mathrm{C}-33.6$; hydrogen $\mathrm{H}$ - 142.9; sulphur S - 9.1.

The biggest amount of thermal energy is released from the combustion of hydrogen; therefore, the specific energy of fuels with a higher content of hydrogen is always higher (Jučas 2006).

The combustion heat of diesel fuels is determined according to LST ISO 8217; for establishing the net heating value of jet fuels, standard ASTM D 4529 is applied.

The cetane number is an indicator that evaluates the auto-ignition properties of diesel fuel and is expressed as the content of cetane (hexadecane) C16H34 in a blend with a-methylnaphtalene.

The cetane number of diesel fuels as well as jet fuels used without any additive and treated with CN value improving additive, which also improves lubricity of the fuel, was established according to standard LST EN ISO 5165.

Lubricity, usually specified according to the wear scar diameter (wsd 1.4 , at $60^{\circ} \mathrm{C}, \mu \mathrm{m}$ ), was evaluated according to standard LST EN ISO 12156 for diesel fuels and jet fuels. Lubricity is a property of a liquid measured according to the trace of wear that appears on a swinging ball due to the contact with a stationary plate immersed in the liquid.

The Cold Filter Plugging Point (CFPP) for diesel fuel defines the properties of fuel flow when it is cold. It is the minimum temperature of the fuel, when the speed of the fuel flowing through a filter at a constant pressure becomes equal to its limited value. In winter, feculences usually appear in diesel fuel. The Cold Filter Plugging Point is a mandatory quality indicator for diesel fuels that is established by laboratory tests according to requirements of LST EN 116 at the Quality Research Center of "ORLEN Lietuva" Ltd.

The Freezing Point is an indicator that defines the limit of fuel fluidity at a low temperature. For jet fuels, the freezing point is established according to the norm provided in ASTM D 2386, and it is the lowest temperature that does not cause the formation of solid crystals of hydrocarbons that may block the fuel flow through the filters of the fuel supply system.

Sulphur content in the fuel, in $\mathrm{mg} / \mathrm{kg}$ or $\mathrm{ppm}$, is established for jet fuels according to the norms provided in ASTM D 5453, whereas for diesel fuels according to the norms provided in LST EN ISO 20846 on burning sulphur $\mathrm{S}$ until the formation of sulphur dioxide $\mathrm{SO}_{2}$ gas; 
then the latter is affected by ultraviolet rays. This method is acceptable for the analysis of fuel with a sulphur content ranging from 1.0 to $8000 \mathrm{mg} / \mathrm{kg}$.

\section{Comparison of the quality indicators of diesel fuel, normal jet fuel and jet fuel treated with additives}

The established quality indicators of diesel fuels (class $\mathrm{C}$ ) and aviation fuels Jet A-1 (F-35), JP-8 (F-34) without additives, with the alkilnitrate additive No. 1 for increasing the cetane number and with two additives (additive No. 1 plus additive No. 2, i.e. Infineum R650 for improvement of lubricity) were compared in the study (Table 1). The fuels were produced according to the Support Agreement signed by and between "ORLEN Lietuva" Ltd and General Jonas Žemaitis Military Academy of Lithuania.

Density. This indicator affects the quality of fuel because fuel supplied to a diesel engine is distributed by volume. According to standard LST EN 590, the density of diesel fuel should be $800-845 \mathrm{~kg} / \mathrm{m}^{3}$. Fuels F-35 and F-34 for turbine-type engines are hydro-treated kerosene. Its density is $775-840 \mathrm{~kg} / \mathrm{m}^{3}$ at the temperature of $15{ }^{\circ} \mathrm{C}$ (Sudintas 2009).

It was found that the measured density of diesel fuel (class C) and jet fuels F-35 and F-34 (Table 1) depends on the fractional and chemical composition of the blend of hydrocarbons that is the base of the fuel tested and on the type of the oil product. Jet fuels are produced from petroleum distillation $\mathrm{C} 8$ - C18 kerosene with a $140-230{ }^{\circ} \mathrm{C}$ fraction. Diesel fuel is a blend of C10 - C29 hydrocarbons with a $180-350^{\circ} \mathrm{C}$ fraction. The density of jet fuels F-35 and F-34 does not alter with the addition of small amounts of additive No. 1 for improving the cetane number or its mixture with the lubricity additive No. 2 .
Specific energy. Fuel is a chemical compound of certain elements, not a simple mechanical mixture, so its specific energy is slightly lower, because a part of thermal energy is normally used for breaking of chemical bonds (Jučas 1999).

The specific energy of all types of fuels under analysis was found to be practically the same, and it corresponds to the specific energy of oil products (diesel fuels and jet fuels).

In the case analysed, the specific energy of jet fuels without an additive and with additive is about the same as the specific energy of diesel fuel. A small increase of the specific energy of jet fuels as compared with the data of diesel fuel was found because the jet fuels include more hydrogen.

The cetane number. A higher cetane number shows that the auto-ignition of diesel fuel caused by high temperature of the air compressed in the cylinder occurs sooner. However, if the cetane number is too high, the in-cylinder compressed air and fuel vapours do not mix properly, thus causing poor combustion of the mixture (Labeckas et al. 2014). In such a case, the engine produces more smoke and operates with lower fuel energy conversion efficiency. According to the ignitibility of the fuel, hydrocarbons are distributed as follows: arenes $<$ cyclohexanes < alkanes. If the number of carbon (C) atoms in a molecule is higher, the cetane number will also be higher. The cetane number of the fuel may be controlled by changing the composition of hydrocarbons or by using additives up to 0.25 vol\% (Jučas 1999, 2006; Sudintas 2009).

The cetane number of diesel fuels is generally within the range of 48-55. For the produced diesel

Table 1. Fuel property parameters

\begin{tabular}{|c|c|c|c|c|c|c|c|}
\hline \multirow{3}{*}{ Property parameters } & \multirow{3}{*}{$\begin{array}{l}\text { Diesel fuel test } \\
\text { method }\end{array}$} & \multirow{3}{*}{$\begin{array}{l}\text { Aviation fuel } \\
\text { test method }\end{array}$} & \multirow{3}{*}{$\begin{array}{l}\text { Diesel fuel } \\
\text { (Grade C) }\end{array}$} & \multicolumn{2}{|c|}{$\begin{array}{l}\text { Aviation fuel JET A-1 } \\
\text { (F-35) }\end{array}$} & \multicolumn{2}{|c|}{$\begin{array}{l}\text { Aviation fuel JP-8 } \\
\text { (F-34) }\end{array}$} \\
\hline & & & & \multirow[t]{2}{*}{$\begin{array}{l}\text { without } \\
\text { additive }\end{array}$} & $\begin{array}{c}\text { with additive } \\
\text { No. } 1\end{array}$ & \multirow[t]{2}{*}{$\begin{array}{l}\text { without } \\
\text { additive }\end{array}$} & $\begin{array}{c}\text { with } \\
\text { additive } \\
\text { No. } 1\end{array}$ \\
\hline & & & & & No. $1+$ No. 2 & & No. $1+$ No. 2 \\
\hline Hydrocarbon mixtures & & & $\mathrm{C} 10-\mathrm{C} 29$ & \multicolumn{2}{|l|}{$\mathrm{C} 8-\mathrm{C} 18$} & \multicolumn{2}{|l|}{$\mathrm{C} 8-\mathrm{C} 18$} \\
\hline Fraction, ${ }^{\circ} \mathrm{C}$ & & & $180-350$ & \multicolumn{2}{|l|}{$140-230$} & \multicolumn{2}{|l|}{$140-230$} \\
\hline Density at $15^{\circ} \mathrm{C}, \mathrm{kg} / \mathrm{m} 3$ & LST EN ISO 12185 & ASTM D 4052 & 843.6 & 797.2 & 797.2 & 791.2 & 791.2 \\
\hline Net heating value, $\mathrm{MJ} / \mathrm{kg}$ & LST ISO 8217 & ASTM D 4529 & 43.10 & 43.30 & 43.27 & 43.23 & 43.23 \\
\hline Cetane number & \multicolumn{2}{|l|}{ LST EN ISO 5165} & 51.3 & 42.3 & 48.5 & 40.6 & 45.2 \\
\hline $\begin{array}{l}\text { Lubricity, corrected wear } \\
\text { scar diameter (wsd } 1,4) \text { at } \\
60^{\circ} \mathrm{C}, \mu \mathrm{m}\end{array}$ & LST EN ISO 12156 & & $\begin{array}{l}277 \\
(\max 460)\end{array}$ & 611 & $\begin{array}{l}729 \\
456\end{array}$ & 822 & $\begin{array}{l}917 \\
454\end{array}$ \\
\hline $\begin{array}{l}\text { Cold filter plugging point } \\
(\mathrm{CFPP}),{ }^{\circ} \mathrm{C} \\
\text { Freezing point, }{ }^{\circ} \mathrm{C}\end{array}$ & LST EN 116 & ASTM D 2386 & -7 & -58 & -58 & -60.3 & -60.4 \\
\hline Sulphur, mg/kg & LST EN ISO 20846 & ASTM D 5453 & 8.9 & 11 & 11 & 11 & 11 \\
\hline
\end{tabular}

Notes: additive No. 1 - 2-EHN;

additive No. 2 - lubricity additive Infineum R650. 
fuel, "ORLEN Lietuva" Ltd applies the quality indicators according to LST EN 590; therefore, the minimum limit values of the cetane number should be about 51 . The cetane number of jet fuels is much lower and varies within the range of 41-42. It was found by this study that the cetane number of the diesel fuel, which was taken as the reference fuel, is about 51.3. The cetane number of jet fuels F-35 and F-34 without the additive No. 1 is 42.3 and 40.6 , respectively. The cetane number increased up to 48.5 (F-35) and 45.2 (F-34), respectively, i.e. by 6.2 units for F-35 and by 4.6 units for F-34 fuels after adding the cetane number improving agent No. 1 to the jet fuel. The use of additive 2-EHN increased the cetane number of jet fuels and improved the auto-ignition properties of the fuel.

Lubricity. The lubricity of jet fuels with the additive No. 1 and without it is poorer than the lubricating properties of diesel fuel: it does not satisfy the required maximum norm of $460 \mu \mathrm{m}$.

One of the problems that may arise in practice when using kerosene-based fuels for vehicles with diesel engines is caused by the poorer lubricating properties of jet fuels produced from lighter fractions of kerosene. Lower lubricity may not cause an instant damage to an engine, but may affect the reliability and durability of diesel engines in a long-term perspective.

Poor lubricating properties of jet fuels can be improved by adding the additive Infineum R650 that increases lubricity. If this is done, lubricity normally defined according to the wear of the diameter (wsd 1.4, at $\left.60{ }^{\circ} \mathrm{C}, \mu \mathrm{m}\right)$ reaches $456 \mu \mathrm{m}(\mathrm{F}-35)$ and $454 \mu \mathrm{m}(\mathrm{F}-34)$, respectively.

Considering the quality parameters, i.e. the cetane number and lubricity, it may be stated that the jet fuels F-35 and F-34 treated with a mixture of additive 2-EHN for increasing the cetane number and additive Infineum R650 for improving the lubricating properties may be used in vehicles with diesel engines.

Cold Filter Plugging Point. When using diesel fuel (class $\mathrm{C}$ ), it is possible to reach a temperature of $-7^{\circ} \mathrm{C}$, which is close to the freezing point of this fossil fuel.

The composition of a diesel fuel affects its operational properties at low temperatures. Since higher boiling point easily ignitable alkanes predominate in diesel fuel composition, they cause the formation of crystals of paraffin at a lower temperature. The fuel quality according to the cold flow characteristics is evaluated by the cloud point, cold filter plugging point, and freezing point (Jučas 1999; Sudintas 2009). Both the cloud point and the cold filter plugging point are controlled by the use of the so called depressants, i.e. ethylene and vinilacetate polymers.

At moderate climate conditions, the cold filter plugging point is the highest temperature when a certain amount of fuel frozen under standard conditions does not flow anymore through standardized filtering equipment within a fixed time (LST EN 116).

At moderate climate conditions, the cold filter plugging point of diesel fuel is divided to six classes; not higher than $+5{ }^{\circ} \mathrm{C}$ (class $\left.\mathrm{A}\right), 0{ }^{\circ} \mathrm{C}$ (class $\left.\mathrm{B}\right),-5{ }^{\circ} \mathrm{C}$ (class C), $10{ }^{\circ} \mathrm{C}$ (class D), $15^{\circ} \mathrm{C}$, and $-20{ }^{\circ} \mathrm{C}$ (class F) (Sudintas 2009).

Kerosene is a jet fuel; its density is lower, and it is more volatile; hence, at temperatures below $0{ }^{\circ} \mathrm{C}$ during the cold period, diesel fuels can be diluted with kerosene.

Jet fuels are produced from the petroleum distillation kerosene fraction by the use of additives. One of these additives is a fuel system anti-icing inhibitor. The freezing point of jet fuels F-35 and F-34 with additives and without them is $-58{ }^{\circ} \mathrm{C}$ and on average $-60.3{ }^{\circ} \mathrm{C}$. If jet fuels are used at high altitudes, where the ambient temperature is below $-50{ }^{\circ} \mathrm{C}$, they do not freeze and freely flow through the tubes of the engine feeding system.

Regarding freezing, the jet fuels with and without additives are more stable compared to diesel fuels.

Sulphur content. The sulphur content in the diesel fuel produced by the oil refnery company "ORLEN Lietuva" Ltd is very low - no more than $10-11 \mathrm{mg} / \mathrm{kg}$ (10$11 \mathrm{ppm})$, so the tested fuels are referred to as sulphur free fuels. The additive 2-EHN and additives Infineum R650 used to improve lubricity do not affect the sulphur content of the jet fuels.

\section{Conclusions}

The quality parameters, such as the cetane number, specific energy, cold filter plugging point, freezing point, lubricity, and sulphur content, of the jet fuels F-35 and F-34 treated with a mixture of the cetane number improving additive 2-EHN and lubricity improving additive Infineum R650 demonstrate that the tested jet fuels may be used in land-based, diesel engine powered vehicles.

\section{References}

ASTM D 1655-15. Standard Specification for Aviation Turbine Fuels. American Society for Testing and Materials.

ASTM D 2386-06: 2012. Standard Test Method for Freezing Point of Aviation Fuels. American Society for Testing and Materials.

ASTM D 4052-11. Standard Test Method for Density, Relative Density, and API Gravity of Liquids by Digital Density Meter. American Society for Testing and Materials.

ASTM D 4529-01. Standard Test Method for Estimation of Net Heat of Combustion of Aviation Fuels. American Society for Testing and Materials.

ASTM D 5453-12. Standard Test Method for Determination of Total Sulfur in Light Hydrocarbons, Spark Ignition Engine Fuel, Diesel Engine Fuel and Engine Oil by Ultraviolet Fluorescence. American Society for Testing and Materials. 
DEF STAN 91-91 AVTUR/FSII. Turbine Fuel, Kerosine Type, JET A-1, NATO Code: F-35, JOINT Servise Designation: AVTUR. ISSUE 7. Publication Date 18 February 2011.

DCSEA 751/B. 2000. Multifunctional additive for diesel engines $S-1750$. Ministry of Defence, Central administration of the French armed forces POL service.

DCSEA 108/A. 2001. Jet diesel fuel without additives XF-63, jet diesel fuel F-63. Defence Ministry of France Republic, Central Board of the Fuel Office at the Army.

EN 590:2014. Automotive fuels - diesel - requirements and test methods. Comité Européen de Normalisation, Brussels.

Graboski, M. S.; McCormick, R. L. 1998. Combustion of fat and vegetable oil derived fuels in diesel engines, Progress in Energy and Combustion. Scientific (24): 125-164.

Jučas, P. 1999. Fuels and lubricants. Vilnius: Mokslas.

Jučas, P. 2006. Chemotology. Classification of fuels and lubricants and technical indexes according ACEA, API, EN, ISO and SAE standards with methodical notes for determining of some parameters. Akademija: LŽŪU Publishing centre.

Labeckas, G.; Slavinskas, S. 2006. The effect of rapeseed oil methyl ester on direct injection diesel engine performance and exhaust emissions, Energy Conversion and Management 47(13-14): 1954-1967.

http://dx.doi.org/10.1016/j.enconman.2005.09.003

Labeckas, G.; Slavinskas, S.; Vilutienè, V. 2014. Effect of the cetane number improving additive on combustion, performance, and emissions of a DI diesel engine operating on JP-8 fuel, Journal of Energy Engineering 141: 14.

Lotko, W.; Lukanin, V. N.; Khatchiyan, A. S. 2000. Usage of alternative fuels in internal combustion engines. Moscow: MADI (Moscow Automobile and Highway Institute). 311 p.

LST EN 116: 1999. Diesel and domestic heating fuels - Determination of cold filter plugging point.

LST EN 590: 2014. Automobiliniai degalai. Dyzelinas. Reikalavimai ir tyrimo metodai. Lietuvos standartizacijos departamentas, 2014.

LST EN ISO 12156-1: 2007. Dyzelinas. Tepumo ìvertinimas naudojant didelio dažnio slankiojamojo judesio stendą (MFRR) [EN ISO 12156-1: 2006, Diesel fuel - Assessment of lubricity using the high-frequency reciprocating rig (HFRR) - Part 1: Test method (ISO 12156-1: 2006)].

LST EN ISO 12185: 1999. Žalia nafta ir naftos produktai. Tankio nustatymas. Vibracinis $U$ vamzdelio metodas [Crude petroleum and petroleum products - Determination of density - Oscillating U-tube method (ISO 12185: $1996+$ ISO 12185: 1996/Cor.1: 2001)].

LST EN ISO 20846: 2004. Naftos produktai. Sieros kiekio automobiliniuose degaluose nustatymas. Ultravioletines fluorescencijos metodas [EN ISO 20846: 2004, Petroleum products - Determination of sulphur content of automotive fuels - Ultraviolet fluorescence method (ISO 20846: 2004)].

LST EN ISO 5165: 1999. Naftos produktai. Dyzelinio kuro užsidegimo kokybes nustatymas. Variklinis cetano metodas [EN ISO 5165: 1998, Petroleum products - Determination of the ignition quality of diesel fuels - Cetane engine method (ISO 5165: 1998)].

LST ISO 8217: 2012. Naftos produktai. Kuras (F klasè). Jūru laivu techniniai reikalavimai (tapatus ISO 8217:2012) [Petroleum products - Fuels (class F) - Specifications of marine fuels (ISO 8217: 2012 identical)].

McDonnell, K. P.; Ward, S. M.; McNulty, P. B.; HowardHildige, R. 2000. Results of engine and vehicle testing of semirefined rapeseed oil, Transactions of the ASAE 43(6): 1309-1316. http://dx.doi.org/10.13031/2013.3027
NATO. 1997. NATO Logistics Handbook. NATO Headquarters, Brussels [online], [cited 29 January 2013]. Available from Internet: http://www.nato.int/docu/logi-en/logist97.htm

Nwafor, O. M.-I. 2004. Emission characteristics of diesel engine operating on rapeseed methyl ester, Renewable Energy (29): 119-129. http://dx.doi.org/10.1016/S0960-1481(03)00133-2 Sudintas, A. 2009. Energetics of the fuel. Kaunas: Technologija.

The representation card 2007 of diesel fuel F-63 used in diesel engines. 2007. Defence Ministry of France Republic, Malakoff.

U.S.MIL-DTL-83133E. Detail Specification: Turbine Fuel, Aviation, KEROSENE TYPE, JP-8 (NATO F-34), NATO F-35 and JP-8 + 100 (NATO F-37) (11 APR 2008) [SUPERSEDING MIL-T-83144D]. 